\title{
Pengaruh Literasi Digital terhadap Psikologis Anak dan Remaja
}

\author{
Nani Pratiwi dan Nola Pritanova \\ Prodi Pendidikan Bahasa dan Sastra Indonesia, Pascasarjana Universitas Negeri \\ Yogyakarta \\ Surel: nanipratiwi01@gmail.com, nola.cnm@gmail.com
}

\begin{abstract}
Abstrak
Penelitian ini bertujuan memaparkan pengaruh literasi yang buruk terhadap psikologis anak dan remaja dalam pengungkapan diri melalui media sosial. Objek dalam penelitian ini adalah komentar-komentar yang dimuat pada situs jejaring sosial facebookdengan fokus masalah Awkarin dan siswa sekolah dasar yang mengunggah foto mesra di facebook. Rumusan masalah dalam penelitian ini adalah (1) apa saja jenis-jenis komentar yang ada pada ungguhan Awkarin dan siswa sekolah dasar yang mengunggah foto mesranya dalam bentuk Meme. (2) Bagaimana dampak psikologis anak maupun remaja terhadap komentar-komentar tersebut? Metode penelitian yang digunakan adalah penelitian kualitatif.Jenis-jenis komentar yang tampak dalam subjek penelitian ini adalah ingratiation, intimidation, dan supplication. Dampak psikologi dari komentar-komentar tersebut terhadap anak dan remaja adalah kecenderungan anak dan remaja terbiasa dengan sikap menghina orang lain, menimbulkan sikap iri terhadap orang lain, mengakibatkan depresi, terbawa arus suasana hati terhadap komentar negatif, serta terbiasa berbicara dengan bahasa kurang sopan.
\end{abstract}

Kata kunci: pengaruh, literasi digital, psikologis anak dan remaja

\section{Pendahuluan}

Saat ini memeroleh informasi sangat mudah. Media digital memudahkan setiap penggunanya untuk saling berbagi informasi. Sumber informasi bisa berasal darimana saja. Era digital tidak dapat dielakkan lagi. Siapapun dapat dengan mudah memanfaatkannya dengan baik, namun tidak jarang juga dapat menghancurkan seseorang. Ketidakpahaman masyarakat terhadap media digital membuat penyalahgunaan yang berakibat terhadap kehidupan pribadi dan sosial.

Media sosial hadir sebagai bagian dari perkembangan internet. Kehadirannya menawarkan cara berinteraksi, berkomunikasi, dan bersosialisasi yang mudah dan baru dengan dukungan fitur yang menarik. Jumlah pengguna media sosial di 
Indonesia didominasi kalangan remaja sehingga dampaknya sangat banyak dirasakan oleh remaja. Penggunaan yang baik dapat meningkatkan prestasi, sebaliknya penggunaan yang buruk dapat berakibat negatif terhadap diri anak dan remaja (Retnowati, 2015: 314).

Contohnya saja saat ini banyak sekali terjadi kasus terkait pencemaran nama baik, penghinaan, prostitusi, penculikan, bullying yang dapat memicu depresi pada anak dan remaja. Kemudahan penyebaran informasi baik yang positif maupun negatif hingga seluruh dunia dan diketahuioleh pengguna media sosial membuat anak dan remaja malu, rendah diri, dan skit hati. Fenomena-fenomena ini menunjukkan pengguna internet di Indonesia belum paham untuk menggunakan internet dengan baik dan benar. Di satu sisi mereka dapat mengakses jaringan, namun belum memahami seutuhnya konsekuensi penggunaan media digital. Jadi, walaupun telah menguasai baca tulis, namun pengguna internet di Indonesia belum sepenuhnya memiliki kemampuan literasi digital.

Berdasarkan penelitian yang dilakukan UNICEF dan Kementerian Komunikasi dan Informatika pada tahun 2015, pengguna internet di Indonesia yang berasal dari anak-anak dan remaja diprediksi sekitar 30 juta. Remaja terlahir dan tumbuh dengan media sosial sebagai bagian dari hidup dan kesehariannya. Saat ini mereka sangat tergantung dengan adanya media sosial. Menurut sebuah agensi marketing sosial, terdapat 72 juta pengguna aktif media sosial pada tahun 2015. Media sosial yang banyak diminati adalah facebook (Retnowati, 2015: 314-315).

Media sosial facebook saat ini sangat diminati seluruh lapisan masyarakat. Bahkan siswa pada tingkat sekolah dasarpun sudah memiliki akun sendiri. Begitu mudahnya akses untuk berselancar di dunia maya membuat orang tua kadang sulit untuk mengontrol aktivitas anak di media sosial.

Di facebook banyak terdapat komunitas-komunitas, seperti komunitas pendaki gunung, komunitas menulis, bahkan ada komunitas meme comics yang isinya cukup mengibur. Akun meme comics ini berisikan gambar-gambar (meme) dan tulisan yang terkadang lucu namun memiliki nilai-nilai untuk menyentak pembacanya agar lebih 
peka terhadap fenomena sosial di sekitar. Tidak jarang, informasi-informasi terbaru di dapat dari akun tersebut.

Pengikut akun meme comis kebanyakan remaja usia sekolah menengah pertama dan sekolah menengah atas. Berkaitan dengan psikologis anak dan remaja, pada usia tersebut tentunya pembaca memiliki emosi yang labil dan mudah terpengaruh. Mereka tidak segan-segan untuk menghina, berkata kasar untuk menunjukkan kekecewaannya, dan kebenciannya terhadap suatu berita. Ini dampak buruk literasi digital yang terjadi saat ini. Fenomena anak dan remaja yang tidak dapat menguasai emosinya, menelan mentah-mentah berita yang ada tanpa berpikir apakah berita tersebut berdampak baginya atau tidak. Rasa keingintahuan (kepo) yang sangat tinggi yang menimbulkan rasa benci berlebihan jika seseorang memberitakan suatu hal yang berlawanan dengan nilai dan norma yang berlaku.

Contohnya berita yang baru-baru ini marak di media sosial yaitu Awkarin dengan status-status akunnya yang kurang sopan, foto-fotonya yang kadang vulgar, video yang menyepelekan lagu kebaangsaan, serta bocah sekolah dasar yang berfoto mesra di facebook. Ada dua tokoh dalam kasus ini, Awkarin dan bocah sekolah dasar.

Pada dasarnya mereka ingin mempresentasikan dirinya dengan cara berfoto mesra, status facebook yang tidak wajar. Mereka melakukannya di akun pribadi masing-masing. Tidak ada yang dirugikan sebenarnya. Akan tetapi media sosial merupakan hakim yang tidak dapat dihentikan. Foto-foto, status-status mereka dibagikan di berbagai akun, salah satunya akun komunitas meme comics. Seketika, seluruh anggota komunitas tersebut memburu akun Awkarin dan bocah sekolah dasar yang berfoto mesra. Walalupun telah disamarkan, namun tidak sulit untuk mencarinya. Setelah itu, admin akun meme comis yang kreatif mulai membuat gambar-gambar yang menyindir Awkarin maupun siswa sekolah dasar yang berfoto mesra tersebut. Alhasil, hampir seluruh anggota komunitas membagikan informasi tersebut dengan alasan untuk memberikan hukuman jera dan sebagian lainnya mungkin hanya untuk menertawakan kebodohan mereka yang mau saja memperlihatkan keburukan sendiri. Tidak hanya itu, pada gambar-gambar meme yang 
dibuat oleh anggota komunitas penuh komentar-komentar yang menyudutkan Awkarin dan bocah sekolah dasar yang berfoto mesra tersebut. Komentar-komentar yang bernada merendahkan, menghina, membanjiri akun komunitas meme comics. Bahkan, akun asli si pelakupun diburu. Akun facebook mereka jadi sasaran perhatian. Akun mereka dipenuhi komentar-komentar yang intinya menyayangkan kelakuan mereka, namun dengan cara yang terkadang menyakitkan hati.

Muncul masalah yang berkaitan dengan literasi digital dan perkembangan psikologi anak dan remaja. Penggunaan facebook sebagai media sosialisasi digital merupakan cara orang memenuhi kebutuhan sosialnya. Anak dan remaja memiliki kebutuhan untuk memiliki dan bersama dalam jaringan sosialnya serta hubungan untuk mengaktualisasikan diri (Tamburaka, 2013: 223). Kebutuhan presentasi diri dipenuhi dengan cara membangun sebuah pandangan yang baik.Media sosial facebook benar-benar memberikan ruang bagi anak dan remaja untuk menunjukkan dirinya di hadapan khalayak. Pada akun facebooknya mereka mempresentasikan diri dengan cara menuliskan kata-kata bijak, mengkritik, menunjukkan kelebihan mereka, menyampaikan aktivitas lewat video, foto, dan sebagainya.

Anak dan remaja berbagi dengan teman-teman di media sosialnya. Mereka membagikan segala kegiatan, foto-foto, dan status-status di facebooknya. Mereka berinteraksi melalui komunikasi tekstual. Mereka beranggapan dengan cara itu mereka akan diterima. Sehingga yang terjadi sebaliknya, muncul penculikan, bullying, dan penipuan.

Oleh karena itu literasi digital dibutuhkan dalam masyarakat, terutama anak dan remaja untuk menyaring informasi yang disajikan di media sosial. Literasi digital diartikan sebagai kemampuan memahami, menganalisis, menilai, mengatur, mengevaluasi informasi dengan menggunakan teknologi digital (Maulana, 2015: 3).Literasi yang buruk dapat mengakibatkan gangguan pada psikologis remaja. Hal ini disebabkan oleh emosi anak dan remaja yang masih belum stabil. Mereka cenderung menerima informasi secara utuh tanpa mencrai tahu informasi tersebut benar apa hanya kicauan di media sosial saja. Ketidakmampuan anak dan remaja memaknai leiterasi digital berdampak pada sikap dak karakter anak dan remaja. 
Mereka terbiasa membaca, mengoementari informasi-informasi yang ada di media sosial. Komentar-komentar tersebut beragam. Jika dianggap informasi tersebut negatif, mereka dengan segera menulis komentar-komentar yang bernada menghina, menjatuhkan, dan merendahkan. Jika informasi tersebut dinilai positif, mereka tidak segan-segan untuk berbagi informasi tersebut di akun miliknya. Fenomena ini tentu bukanlah yang diharapkan. Oleh karena itu solusi terbaik yang harus dilakukan pada anak dan remaja adalah memberikan pembelajaran literasi digital karena cepat atau lambat literasi digital yang buruk akan berdampak terhadap karakter dan psikologis anak dan remaja.

Tujuan penelitian ini memaparkan pengaruh literasi digital yang buruk terhadap psikologis anak dan remaja dalam pengungkapan diri melalui media sosial. Pendeskripsian cara anak dan remaja merespon status-status di facebook, foto-foto yang dibagikan akun lain dengan pemahaman literasi digital yang buruk yang berujung pada permasalahan terhadap sikap dan tingkah laku, bahkan kejiwaannya.

Manfaat penelitian ini agar pengguna facebook, khususnya anak dan remaja memahami pentingnya pemahaman literasi digital daan dampak buruknya terhadap diri. Selain itu, bagi orang tua agar lebih mengawasi anak-anak sebagai pengguna sosiam media seperti facebook.

Objek dalam penelitian ini adalah komentar-komentar yang dimuat pada situs jejaring sosial facebook dengan fokus masalah Awkarin dan siswa sekolah dasar yang mengunggah foto mesra di facebook. Rumusan masalah dalam penelitian ini yaitu: 1) apa saja jenis-jenis komentar yang ada pada ungguhan Awkarin dan siswa sekolah dasar yang mengunggah foto mesranya dalam bentuk Meme, 2) bagaimana dampak psikologis anak maupun remaja terhadap komentar-komentar tersebut? Metode penelitian yang digunakan adalah kualitatif deskriptif analitis.

\section{Landasan Teori}

\section{a. Literasi Digital}


Saat ini penyebaran informasi yang terjadi di dunia sangat cepat. Sumber informasi bisa datang darimana saja. Wartawan menulis berita kemudian dibagikan lewat media sosial sehingga pendistribusian informasi bergerak dengan cepat. Tidak hanya berita yang ditulis oelh wartawan, berita maupun informasi yang ditulis oleh orang biasapun kerapkali sering dibagikan lewat media sosial seperti blog, facebook, twitter, dan sebagainya (Haryanto, 2014: 173). Respon terhadap beritapun beragam, tentunya ada yang mendukung dan begitu pula sebaliknya.

Selama ini literasi dipahami sebagai kegiatan membaca dan menulis. Hingga pada akhirnya literasi tidak hanya berkaitan dengan baca tulis. Tetapi mencakup kemampuan membaca, memahami, dan mengeapresiasi berbagai bentuk komunikasi secara kritis (Indriyana, 2016:1-2). Pada masa perkembangan awal, literasi diartikan sebagai kemampuan untuk menggunakan bahasa dan gambar dalam bentuk yang kaya dan beragam untuk membaca, menulis, mendengarkan, berbicara, melihat, menyajikan, dan berpikir kritis tentang ide-ide. Perkembangan berikutnya menyatakan bahwa literasi berkaitan dengan situasi dan praktik sosial. Kemudian, literasi diperluas oleh semakin berkembangnya teknologi informasi dan multimedia. Setelah itu, literasi dipandang sebagai konstruksi sosial dan tidak pernah netral (Abidin, 2015: 49-50).

Tamburaka (2013: 72) menyatakan dengan adanya perkembangan teknologi di bidang teknologi informasi memicu perubahan besar dalam teknologi digitalisasi, yaitu kondisi semua konten media cetak dan elektronik dapat digabungkan dan didistribusikan. Gilster (dalam Maulana, 2015: 3) mengartikan literasi digital sebagai kemampuan memahami dan menggunakan informasi dalam banyak format dari berbagai sumber ketika itu disajikan di komputer. Retnowati (2015: 314) mengemukakan bahwa literasi media atau literasi digital dikembangkan sebagai alat untuk melindungi orang dari terpaan media agar memiliki kemampuan berpikir kritis serta mampu mengekspresikan diri dan berpartisipasi dalam media.

Caniago (2013: 8) mengartikan literasi digital mencakup pemahaman tentang web dan mesin pencari. Literasi digital juga dapat diartikan sebagai himpunan sikap, pemahaman, dalam menangani dan mengomunikasikan informasi dan pengetahuan 
secara efektif dalam berbagai media dan format. Bawden (dalam Caniago, 2013: 6) berpendapat bahwa literasi digital merupakan kemampuan untuk berhubungan dengan informasi hipertekstual dalam arti bacaan yang berurut berbantuan komputer. Secara umum, literasi digital adalah kemampuan untuk berhubungan dengan informasi hipertekstual dalam arti memnaca non-sekuensial atau non urutan berbantuan komputer.

Literasi media atau literasi digital harus mengembangkan kemampuan untuk mengembangkan kemampuan khalayak baik secara intelektual yaitu pendidikan literasi media dalam memahami pesaan media yang khas. Mengembangkan kemampuan emosi, merasakan hal yang diarsakan diri sendiri dan orang lain dari suatu pesan. Mengembangkan kematangan moral dalam kaitannya dengan konsekuensi moralitas bagi setiap orang (Tamburaka, 2013: 13). Literasi media bergerak untuk melihat pengaruh buruk yang dapat ditimbulkan oleh pesan-pesan media dan belajar mengantisipasinya (Tamburaka, 2013: 14).

\section{b. Psikologi Anak dan Remaja}

Jones (via Retnowati, 2015: 321-322) mengemukakan bentuk-bentuk anak dan remaja mempresentasikan dirinya terhadap situasi interpersonal di media sosial meliputi ingratiation, competence, intimidation, exemplification, dan supplication.

\section{1) Ingratiation}

Bentuk ini menunjukkan bahwa pengguna sosial media memberikan komentar atau status di facebook tentang hal yang disukai orang lain terhadap dirinya atau sedikit tentang hal-hal negatif tentang dirinya sendiri. Hal ini bertujuan untuk menyatakan kesederhanaan, keakraban, dan humor. Misalnya memberikan apresiasi terhadap foto-foto pengguna lainnya atau berbalas-balasan status atau komentar.

\section{2) Competence}

Bentuk ini menunjukkan bahwa pengguna media sosial ingin dianggap terampil dan berkualitas. Beberapa pengguna media sosial dengan profesi tertentu, misalnya analis politik akan menggunakan akun media sosialnya untuk memberikan tanggapan 
mengenai kondisi politik saat ini. Tentu akan mengupayakan untuk menunjukkan kompetensinya. Begitu juga media sosial yang fokus ke karya seni akan berupaya sebaik mungkin menampilkan karya-karyaterbaik di media sosialnya.

\section{3) Intimidation}

Bentuk ini bertujuan untuk memperoleh kekuasaan. Karakteristik umum yang dimiliki adalah ancaman, pernyataan kemarahan, dan kemungkinan ketidaksenangan. Bentuk ini bisa dilihat dari akun-akun media sosial pengguna yang mengekspresikan rasa tidak suka atau tidak setuju dengan sangat ekspresif.

4) Exemplification

Bentuk ini digunakan oleh pengguna media sosial agar dianggap secara moral lebih unggul atau memiliki standar moral yang lebih tinggi. Karakter umumnya adalah komitmen ideologis atau militansi, pengorbanan diri, dan kedisiplinan diri. Umumnya berupa foto atau gambar-gambar bersifat nasionalis dan mengandung unsur ideologi tertentu.

\section{5) Supplication}

Bentuk ini menunjukkan ketidakberdayaan sehingga orang lain akan datang untuk membantu orang tersebut. Karakter dari pendekatan presentasi diri termasuk memohon bantuan dan rendah diri. Pengguna terkadang menulis "apa lagi cobaan yang akan datang", "saya sudah tidak sanggup lagi”, dan beberapa tulisan lain yang menunjukkan dirinya sedang tidak berdaya atau dalam kondisi yang kurang bagus.

\section{Hasil dan Pembahasan}

Terdapat tiga gambar meme yang dibagikan pada komunitas meme comics yang cukup heboh terkait Awkarin, dan dua gambar meme terkait bocak sekolah dasar yang berfoto mesra. Tiga gambar meme tersebut berjudul: 1) Kalo kata orang ini, "Nakal Boleh, Bego jangan". Kalo lu udah bisa bedain mana yang nakal dan mana yang engga, kenapa lu malah pilih untuk jadi nakal? Bego kan berarti. Gambar ini diberi like sebaanyak 36.148 dan 2.007 komentar anggota komunitas. 2) "Baju kurang bahan, suka ngomong kasar, bau asap rokok, sungguh bukan calon mantu ideal". Gambar ini diberi like sebanyak 31.876 dan 2.366 komentar. 3) "Nakal kok bangga, 
malu sama yang udah tobat". Gambar ini diberi like sebanyak 24.312 dan 1.213 komentar.

Terdapat dua gambar meme terkait foto mesra anak sekolah dasar, yaitu: 1) Gambar yang membagikan akun facebook dan foto mesra anak sekolah dasar tersebut dengan jumlah like sebanyak 16.034 dan 1.828 komentar. 2) Gambar kedua berjudul, "Yaelah tong, sepatu aja masih dipasangin emak udah stay with me aja", dengan like sebanyak 35.821 dan 3.758 komentar. Tidak hanya itu, pada akun asli Awkarin dan bocah sekolah dasar tersebut juga banyak serangan komentar baik yang mendukung maupun yang membenci mereka. Komentar yang mendukung sikap Awkarin maupun sikap anak sekolah dasar tersebut biasanya juga akan dibalas oleh akun-akun lain yang tidak suka dengan Awkarin dan bocah anak sekolah dasar tersebut. Akhirnya terjadi perang komentar antara pendukung dan bukan pendukung Awkarin dan bocah sekolah dasar.

Sebagian besar komentar terhadap Awkarin dan bocah sekolah dasar yang berfoto mesra menunjukkan ketidaksukaan, kritik, bahkan terkesan menghujat. Tidak hanya kepada mereka berdua saja, bahkan orang tuanya. Hal ini terjadi karena mereka dirasa masih dalam batas usia yang seharusnya diawasi orang tua, khususnya pada kasus yang terjadi pada anak sekolah dasar tersebut. Berikut ini akan dipaparkan data terkait komentar seputar Awkarin dan bocah sekolah dasar yang berfoto mesra oleh pengguna facebook.

Tabel 1

Persentase Jumlah Komentar Pengguna Facebook yang Termasuk Situasi Interpersonal Ingration, Intimidation, dan Suplication

\begin{tabular}{|c|c|c|c|c|c|}
\hline \multirow{2}{*}{ No } & \multicolumn{3}{|c|}{ Awkarin } & \multicolumn{2}{c|}{ Bocah Sekolah Dasar } \\
\cline { 2 - 6 } & $\begin{array}{c}\text { Jenis Situasi } \\
\text { Interpersonal }\end{array}$ & $\begin{array}{c}\text { Jumlah } \\
\text { Komentar }\end{array}$ & Persentase & $\begin{array}{c}\text { Jumlah } \\
\text { Komentar }\end{array}$ & Persentase \\
\hline 1. & Ingratiation & 17 & $35,4 \%$ & 5 & $31,25 \%$ \\
\hline 2. & Intimidation & 29 & $60,4 \%$ & 11 & $68,75 \%$ \\
\hline 3. & Suplication & 2 & $4,2 \%$ & 0 & 0 \\
\hline
\end{tabular}


Total

48

\begin{tabular}{l|l}
$100 \%$ & 16
\end{tabular}

$100 \%$

Pada komentar-komentar yang terdapat pada gambar-gambar meme, bahkan beberapa komentar juga ada pada akun Awkarin maupun siswa sekolah dasar, terdapat tiga jenis situasi interpersonal yang sangat menonjol. Situasi ini terkait dengan perkembangan psikologi anak dan remaja dalam memperesentasikan dirinya di hadapan publik, dalam hal ini di hadapan media sosial facebook. Pada komentarkomentar tersebut akan terlihat cara anak dan remaja menanggapi suatu informasi terkait dengan kemampuan literasi digitalnya.

Situasi ingratiation menunjukkan bagaimana komentar yang dilontarkan secara tertulis oleh pengguna facebook dapat menarik perhatian pengguna lainnya. Komentar yang diberikan cenderung positif, memperlihatkan hal yang baik, menunjukkan kelebihan, agar disukai dan disenangi. Pada kasus Awkarin ditemukan 17 contoh komentar $(35,4 \%)$ dan pada kasus bocah sekolah dasar ditemukan $5(31,25 \%)$ komentar. Komentar-komentar yang dipilih ini merupakan komentar yang paling menunjukkan situasi ingration di antara ribuan komentar. Misalnya, pada kasus Awkarin, terdapat komentar, "semua manusia gak luput dari dosa, dia begitu hari ini, esok kita gak pernah tau lagi mungkin dia akan menjadi lebih baik lagi dari kalian para penghujat. Manusia hidup punya jalan cerita masing-masing”. Dari kalimat tersebut menunjukkan bahwa pemilik akun berusaha bersikap biasa, bahkan dapat dikatakan membela karena sebagian besar menghujat Awkarin. Begitu juga dengan akun lainnya, "Karin nggak pernah ngerepotin orang tua. Emang Karin nggak kerja, tapi bisnisnya lebih dari kalian semua. Kuliah, duit dapat sendiri. Emang elu? Duit ngemis nyokap aja songong".

Pada kasus bocah sekolah dasar terlihat situasi ingratiation, "Ssop bullynya, kasihan dia masih anak-anak. Takutnya nanti dia putus asa trus bunuh diri. Namanya juga anak-anak...". Kemudian akun lain menuliskan, "Indonesia dengan moral sebagian anak-anak yang miring. Mari bersama-sama mendidik hal yang baik dan benar pada anak-anak penerus bangsa...". Selanjutnya, "terima kasih pada KPI, kepada orang tua yang tak peduli mendidik anak, dan terima kasih pada sinetron 
Indonesia”. Tiga komentar tersebut menunjukkan bahwa pemilik akun bersikap netral, cenderung membela karena menganggap tu tidak hanya kesalahan mereka, tapi ada pihak lain seperti orang tua.

Kemudian, pada situasi intimidation. Situasi ini bertujuan untuk menunjukkan kekuasaan dengan cara mengancam, marah, dan menunjukkan ketidaksenangan dengan cara ekspresif. Pada kasus Awkarin terdapat 29 komentar $(60,4 \%)$ dan kasus bocah sekolah dasar 11 komentar (68,75\%). Contoh komentar yang menunjukkan intimidasi terhadap Awkarin yaitu, "hanya sekumpulan orang idiot bin sarap berlindung di kata-kata terserah gue dan gue gak munafik. Cuma orang goblok yang mau ngikutin nih orang. Ultimate goblok". Selanjutnya, komentar serupa dilontarkan seperti berikut ini, "kenapa nggak sekalian ambil pedang dan penggal kepala menjijikkanmu itu!!”. Dua komentar tersebut telah menunjukkan rasa tidak suka dan benci pada prilaku yang ditunjukkan Awkarin di sosial media. Bahkan terkesan iri karena Awkarin tetap banyak memiliki pendukung yang membela sikapnya. Selanjutnya, pada kasus bocah sekolah dasar yang berfoto mesra, terlihat pada komentar berikut, "itu anak dibikin asal-asalan entah di luar nikah apa gimana. Kagak dididik bener ama ortunya. Kagak dipeduliin pergaulannya...". Kemudian pada akun lain, “Penuh dosa apaan! Dosa juga masih emak lu yang nanggung, bego!!”. Pada dua komentar tersebut juga terlihat rasa tidak suka pengguna facebook terhadap foto dan status yang dibagikan oleh akun bocak sekolah dasar yang berfoto mesra.

Terakhir, pada situasi suplication yang berisi ketidakberdayaan pengguna sosial media. Pada kasus Awkarin, terdapat 2 komentar $(4,2 \%)$ yang menunjukkan ketidakberdayaan Awkarin, yaitu "kalian boleh hina aku sepuasnya, kalian suci aku penuh dosa". Kalimat itu sering diucapkan oleh Awkarin sebagai bentuk jawaban bagi para pembencinya. Sementara untuk kasus bocah sekolah dasar tidak ditemukan komentar sejenis.

Tingginya tingkat 'mengintimidasi' oleh anak dan remaja menunjukkan sikap dan karakter pengguna facebook yang menghakimi. Mereka dengan mudah terbawa suasana hati, terpancing oleh status negatif di facebook. Hal ini dapat membuat 
depresi, karena kecenderungan yang berlebihan terhadap media sosial. Apapun dikomentari, dikritik, dan dibagikan. Hal ini tentu saja berkaitan dengan pemahaman terhadap literasi digital yang berpengaruh pada psikologis anak dan remaja. Mereka dengan mudah menghina, menyudutkan, bahkan menghujat, cenderung merendahkan orang lain tanpa berpikir terlebih dahulu dampak atas prilaku mereka. Kebiasaan ini akan merusak diri anak dan remaja. Terbiasa mengomentari, mengkritik, mencaci, berkata kasar di media sosial justru menunjukkan bahwa prilaku dan karakter mereka cacat. Hal ini akan membuat rasa ketagihan pada diri anak dan remaja yang dapat berdampak buruk terhadap kejiwaannya. Anak dan remaja akan gamang menjalani kehidupannya, takut jika tingkahnya juga akan disorot, kemudian dijadikan bahan tertawaan di media sosial.

Dua kasus ini menunjukkan rendahnya pemahaman terhadap literasi digital membuat anak dan remaja kehilangan identitasnya. Status dan foto-foto yang disajikan di media sosial memicu orang-orang untuk mengomentari dan mengkritisi tingkah mereka. Akan tetapi komentar yang berisi kritikan dengan dalih sebagai sanksi sosial itu terkadang keterlaluan, bahkan samapai ada yang menghina orang tua. Kondisi ini dapat mengganggu perkembangan psikologis anak dan remaja. Hal ini akan berdampak pada sikap dan tingkah lakunya yang suka meremehkan, menghina, mencampuri urusan orang lain. Selain itu dalam kehidupan sehari-hari mereka akan cenderung takut bersosialisasi 'apa adanya' karena terbiasa mencampuri urusan orang lain, mereka akan takut untuk bersikap. Mereka beranggapan orang lain akan menyoroti sikap, tingkah laku, dan kehidupan pribadinya.

\section{Kesimpulan}

Literasi digital merupakan era perkembangan baru dunia baca tulis. Seluruh informasi dengan mudah diperoleh melalui media sosial. Semua berita disajikan dengan cepat, namun terkadang tidak akurat, karena kecepatan pemberitaan yang terpenting. Berbagai situs berita bermunculan, akun-akun komunitas bermunculan, dan sebagainya. Intinya berbagi informasi, baik mengenai orang lain maupun diri 
sendiri. Hal ini menyebabkan rasa ingin tahu pengguna sosial media, dalam hal ini facebook, meningkat.

Oleh karena itu pemahaman akan dampak buruk literasi digital perlu ditekankan pada pengguna, terutama anak dan remaja. Sebab, pengguna terbesar facebook adalah anak dan remaja. Mereka menggunakan facebook sebagai media aktualisasi diri. Seperti dua sisi mata uang, era literasi digital dapat memperbaiki keadaan, dapat juga memperburuk keadaan. Peran orang tua sangat penting dalam hal ini untuk mengawasi tingkah laku anak dan remaja. Pemahaman literasi digital yang buruk akan berpengaruh pada psikologis anak dan remaja yang cenderung menghina orang lain, menimbulkan sikap iri terhadap orang lain, mengakibatkan depresi, terbawa arus suasana hati terhadap komentar negatif, serta terbiasa berbicara dengan bahasa kurang sopan.

\section{Daftar Pustaka}

Caniago, Junita Kahirani. 2013. Literasi Media dan Literasi Digital. (Diunduh tanggal 15 Oktober 2016, pukul 14.10 WIB) http://junitakhairanicaniago.weebly.com/-uploads/1/8/4/6/18468290/makalah literasi media digital.pdf

Haryanto, Ignatius. 2014. Jurnalisme Era Digital. Jakarta: Kompas.

Indriyana, Hasta. (September 2016). Mendorong Terciptanya Pembelajar Mandiri. Makalah disajikan dalam Seminar Nasional Budaya Literasi untuk Menumbuhkan Generasi Cendekia dan Literat, di Fakultas Bahasa dan Seni Uiversitas Negeri Yogyakarta.

Maulana, Murad. 2015. Definisi, Manfaat, dan Elemen Penting Literasi Digital. (Diunduh tanggal 15 Oktober 2016, pukul 14.00 WIB) http://www.muradmaulana.com/-2015/12/definisi-manfaat-dan-elemenpenting-literasi-digital.html

Retnowati, Yuni. 2015. Urgensi Literasi Media untuk Remaja Sebagai Panduan Mengkritisi Media Sosial. (Diunduh tanggal 2 Ontober 2016) 
http://akindo.ac.id/downlot.php?file=13Urgensi\%20Literasi\%20Media\%20u ntuk\%20Remaja\%20Sebagai\%20Panduan\%20Mengkritisi\%20Media\%20So sial.pdf

Tamburaka, Apriadi. 2013. Literasi Media. Jakarta: PT Raja Grafindo Persada.

Triwikromo, Triyanto. (6 Oktober 2016). Perihal Nasib Bahasa dan Sastra Indonesia Mutakhir. Makalah disajikan dalam Sarasehan Kebahasaan dan Kesastraan Tahun 2016, di Balai Bahasa Daerah Istimewa Yogyakarta. 